\title{
Correction to: Gender Differences in Risk-Taking and Sensation-Seeking Behavior: Empirical Evidence from "ExtremeSports"
}

\section{Bernd Frick ${ }^{1}$ (1)}

Published online: 7 July 2021

๑) Springer Science+Business Media, LLC, part of Springer Nature 2021

\section{Correction to: De Economist (2021) 169:5-20 https://doi.org/10.1007/s10645-020-09373-y}

The article: "Gender Differences in Risk-Taking and Sensation-Seeking Behavior: Empirical Evidence from "ExtremeSports"”, written by Bernd Frick, was originally published electronically on the publisher's internet portal on 10 September 2020 without open access. With the author(s)' decision to opt for Open Choice the copyright of the article changed on 07 July 2021 to (CThe Author(s) 2021 and the article is forthwith distributed under a Creative Commons Attribution 4.0 International License, which permits use, sharing, adaptation, distribution and reproduction in any medium or format, as long as you give appropriate credit to the original author(s) and the source, provide a link to the Creative Commons licence, and indicate if changes were made. The images or other third party material in this article are included in the article's Creative Commons licence, unless indicated otherwise in a credit line to the material. If material is not included in the article's Creative Commons licence and your intended use is not permitted by statutory regulation or exceeds the permitted use, you will need to obtain permission directly from the copyright holder. To view a copy of this licence, visit http://creativecommons.org/licen ses/by/4.0/. The original article has been corrected.

Publisher's Note Springer Nature remains neutral with regard to jurisdictional claims in published maps and institutional affiliations.

The original article can be found online at https://doi.org/10.1007/s10645-020-09373-y.

Bernd Frick

bernd.frick@uni-paderborn.de

1 Management Department, Paderborn University, Warburger Strasse 100, 33098 Paderborn, Germany 